\title{
Protectibility of Trademark Values Against False Competitive Advertising
}

\author{
Gilbert $H$. Weil*
}

Advertising and promotional methods of the past few decades have added a new dimension to trademarks.

In earlier eras of merchandising, the source of a product was probably its principal selling point. The trademark, standing as identification of the producer, was a symbol of origin and conveyed to the buying public the distillation of what was then the important sales message.

Subsequently, by the spectacular use of methods for the mass communication of merchandising imformation, ${ }^{1}$ increased stress came to be placed upon the quality and special performance attributes of the individual brands of goods. This served to shift the emphasis away from the place of origin and toward the particular product itself. The article was invested with its own distinctive personality in the eyes of the consuming public. In the more graphic language of advertising people, a "consumer franchise" was created; or a "product image" or "product personality" was built for the item.

The major commercial import of a trademark, in the main, thus moved from one of pedigree to one of portrait. Today the trademark function of summarizing and symbolizing the product image molded by the cumulative power of its advertising and relating it at the point of sale to a specific purchasable unit of the commodity must be understood as a shorthand communication of product qualities and performance specifications.

The good will which attaches to a product by virtue of its performance capabilities is relative, and depends upon how it compares with the corresponding capacities of competing articles.

The sales appeal (good will) which can be created by advertising that an automobile will achieve twenty miles per gallon at 40 miles an hour depends upon whether rival cars claim to equal or surpass that standard. The value of the trademark, since it is but the symbol and repository of the product's good will, tends to vary correspondingly.

It seems quite plain that, in the light of such current marketing concepts, an advertiser who lays claim to performance characteristics which make his product more desirable than those of his competitors enhances his own trademark at the expense and diminution of theirs. If he does so falsely he does so unfairly, and an unfair assault upon the trademark values

* Member of the New York Bar.

${ }^{1}$ As exemplified by, but not confined to, the formal media of advertising. 
of a competitor should not, by fundamental equitable principles, stand irremediable.

The failure of courts to have come to this result, virtually as a matter of course, is probably due to the fact that the line of cases dealing with this branch of the law originated at a time when trademark damage as the result of false advertising ${ }^{2}$ was a remote threat at most.

Thus, in 1890, when Nere York \& $R$. Cement Co. v. Coplay Cement $\mathrm{Co} .{ }^{3}$ the first important case in this line, was decided, the conceptual development of the court was such that it could not think in terms of any trademark damage or unfair competition, other than by simulation or passing off. Almost by definition, therefore, it could find no "property right" belonging peculiarly to a private plaintiff which might be violated by a defendant's false advertising; and it would not recognize in such plaintiff the right to prosecute as a private avenger for a public wrong, fearing that to do so would open the door to a flow of vexatious litigation.

The defendant had designated its product as "Rosendale" cement. Actually, its plant was not located in Rosendale, nor did its product come from there. Plaintiff, as well as others, was truly a Rosendale producer. The rationale of the decision is well illustrated in the following language of the court: ${ }^{4}$

No doubt the sale of spurious goods, or holding them out to be different from what they are, is a great evil, and an immoral, if not an illegal act; but unless there is an invasion of some trade-mark, or trade-name, or peculiarity of style, in which some person has a right of property, the only persons legally entitled to judicial redress would seem to be those who are imposed upon by such pretenses. ... No man can maintain a private action for a public nuisance, though he is injured by it, unless his injury is of a special character, different from that which is sustained by the public generally.... If it be said that the cement manufacturers of Rosendale are specially injured, because their trade is affected, it may be properly answered that they are all injured alike. It is a public injury as to them.... It is a damage to the complainants and the other cement manufacturers of Rosendale ... but, like many other cases of damage ... it is of that kind which the law calls damnum absque injuria. The defendants may lay themselves open to prosecution by their customers, or possibly by the state, if they are guilty of falsely selling their cement as of a class or sort to which it does not belong, but that is no reason for sustaining an action against them at the suit of those who deal in such cement. In our view, if a person seeks to restrain others from using a particular trade-mark, trade-name, or style of goods, he must show that he has an exclusive ownership or property therein. To show that he has a mere right, in common with others, to use it is insufficient.

2 I.e., damage in a factual commercial context-hence in legal contemplation as well.

344 Fed. 277 (C.C.E.D.Pa. 1890).

4 Id. at 278-79. 
The thinking of the Rosendale Cement case was followed and given momentum by American Washboard Co. v. Saginaw Mfg. Co., ${ }^{5}$ where the defendant, falsely claiming that its washboards were made of aluminum, was sued by the exclusive manufacturer of genuine aluminum washboards. In denying the plaintiff recovery, the court said: "If the doctrine contended for by complainant in this case was to be carried to its legitimate results, we should, as suggested by Mr. Justice Bradley in [Coplay] . . . open a Pandora's box of litigation. A person wlio undertook to manufacture a genuine article could suppress the business of all untruthful dealers, although they were in no wise undertaking to pirate his trade."

American Washboard was in turn slavishly followed as a precedent in Bor ien's Condensed Milk Co. v. Horlick's M.M. Co., ${ }^{7}$ where it was alleged that the defendant had falsely represented its product as "the original malted milk," and in Armstrong Cork Co. v. Ringwalt Linoleum Works, ${ }^{\mathrm{s}}$ involving defendant's misuse of "linoleum" as a description of its product.

By 1925 evolution in the marketplace had evidently progressed and begun to infiltrate the judicial consciousness sufficiently to cause the Court of Appeals for the Second Circuit in Ely-Norris Safe Co. v. Mosler Safe $\mathrm{Co}^{9}$ to recognize that if sales were actually diverted from one competitor to another through the use of false advertising, there was enough by way of commercial injury [property right(?)] to warrant intervention by a court of equity. The plaintiff im that case manufactured safes which embodied a patented device known as an explosion chamber. Defendant also

5103 Fed. 281 (6th Cir. 1900).

6 Id. at 285-86. The court continued its argument, quoting from the Coplay ("Rosendale" cement) decision: "Says Mr. Justice Bradley:

"The principle for which counsel for complainant contends would enable any crockery merchant of Dresden or elsewhere interested in the particular trade to sue a dealer of New York or Philadelphia who should sell an article as Dresden chima, when it is not Dresden china .... A dry-goods merchant selling an article of linen as Irish linen could be sued by all the haberdashers of Ireland and all the linen dealers of the Umited States.'

"Take the metal which is the subject-matter of the controversy in this case. Many articles are now being put upon the market under the name of aluminum, because of the attractive qualities of that metal, which are not made of pure aluminum, yet they answer the purpose for which they are made and are useful. Can it be that the courts have the power to suppress stich trade at the instance of others starting in the same business who use only pure aluminum? There is a wide-spread suspicion that many articles sold as being inanufactured of wool are not entirely made of that material. Can it be that a dealer who should make such articles only of pure wool could invoke the equitable jurisdiction of the courts to suppress the trade and busimess of all persons whose goods may deceive the public? We find no such authority in the books, and are clear in the opinion that, if the doctrine is to be thus extended, and all persons compelled to deal solely in goods which are exactly what they are represented to be, the remedy must come from the legislature, and not from the courts."

7206 Fed. 949 (E.D. Wis. 1913).

8235 Fed. 458 (D. N.J. 1916).

97 F.2d 603 (2d Cir. 1925), rev'd sub nom., Mosler Co. v. Ely-Norris Co., 273 U.S. 132 (1927). 
manufactured safes with an explosion chamber, using a metal band around such safes to indicate this special feature. ${ }^{10}$ The gravamen of plaintiff's action for unfair competition was that im many instances defendant used the metal band on safes which did not in fact incorporate the explosion chamber, thus falsely representing their embodiment of that feature.

Judge Learned Hand, writing for the court, was impressed with the argument that buyers who wished to purchase a safe with an explosion chamber in it and who were deceived into patromizing the defendant by virtue of its misrepresentation could only have been diverted from the plaintiff, as it was the sole competing source of supply for that kind of product. He distinguished the "Rosendale cement" case on the ground that since there were a number of Rosendale manufacturers it did not sufficiently appear that diversion of sales, if any, was necessarily from the particular plaintiff in that case rather than from some of the other Rosendale manufacturers. He found himself unable to make such a differentiation with regard to the American Washboard case, since it appeared that the plaintiff there was the exclusive producer of aluminum washboards. He therefore had to take issue with that case upon the basic law. In the core of the decision sustaining the complaint against a demurrer, he said: ${ }^{11}$

We must concede, therefore, that on the cases as they stand the law is with the defendant, and the especially high authority of the court which decided [American Washboard] makes us hesitate to differ from their conclusion. Yet there is no part of the law which is more plastic than unfair competition, and what was not reckoned an actionable wrong 25 years ago may have become such today. We find it impossible to deny the strength of the plaintiff's case on the allegations of its bill. As we view it, the question is, as it always is in such cases, one of fact. While a competitor may, generally speaking, take away all the customers of another that he can, there are means which he must not use. One of these is deceit. The false use of another's name as maker or source of his own goods is deceit, of which the false use of geographical or descriptive terms is only one example. But we conceive that in the end the questions which arise are always two: Has the plaintiff in fact lost customers? And has he lost them by means which the law forbids? The false use of the plaintiff's name is only an instance in which each element is clearly shown.

In the case at bar the means are as plainly unlawful as in the usual case of palming off. It is as unlawful to lie about the quality of one's wares as about their maker; it equally subjects the seller to action by the buyer.... The reason, as we think, why such deceits have not been regarded as actionable by a competitor, depends only upon his inability to show any injury

10 In an entirely separate action plaintiff claimed that defendant's use of the explosion chambers constituted patent infringeinent. Ely Norris Safe Co. v. Mosler Safe Co., 62 F.2d 524 (2d Cir. 1933).

11 Ely-Norris Safe Co. v. Mosler Safe Co., 7 F.2d 603, 604 (2d Cir. 1925), rev' sub nom., Mosler Co. v. Ely-Norris Co., 273 U.S. 132 (1927). 
for which there is a known remedy. In an open market it is generally impossible to prove that a customer, whom the defendant has secured by falsely describing his goods, would have bought of the plaintiff, if the defendant had been truthful. Without that, the plaintiff, though aggrieved in company with other honest traders, cannot show any ascertainable loss. He may not recover at law, and the equitable remedy is concurrent. The law does not allow him to sue as a vicarious avenger of the defendant's customers.

But, if it be true that the plaintiff has a monopoly of the kind of wares concerned, and if to secure a customer the defendant must represent his own as of that kind, it is a fair inference that the customer wants those and those only. Had he not supposed that the defendant could supply him, presumably he would have gone to the plaintiff, who alone could. At least, if the plaintiff can prove that in fact he would, he shows a direct loss, measured by his profits on the putative sale. If a tradesman falsely foists on a customer a substitute for what the plaintiff alone can supply, it can scarcely be that the plaintiff is without remedy, if he can show that the customer would certainly have come to him, had the truth been told.

Thus, the legal issue was drawn by the Ely-Norris case between its own holding that equity would give redress to a plaintiff if he could prove that false advertising had caused him to lose sales to a competitor, and the earlier decisions which held that as a matter of substantive law no right of action existed even if plaintiff could prove such direct injury.

Upon certiorari the Supreme Court straddled that legal issue by reversing the court of appeals' decision, but merely upon the ground that the direct conflict which Judge Hand envisaged between Ely-Norris and American Washboard did not exist, since the allegations in the Ely-Norris complaint left room for the possibility that persons other than the plaintiff manufactured safes with explosion chambers. ${ }^{12}$

The peculiar holding of the Supreme Court, although not expressed in such terms, seems inescapably to be that a plaintiff who is not the exclusive competitor of a false advertiser as a matter of law cannot prove the injury requisite to sustain a cause of action.

The Supreme Court did not decide whether, as a substantive proposition, a cause of action exists in favor of a plaintiff if it can show actual injury from false competitive advertising. It merely failed (or refused) to recognize that a plaintiff, even though he does not enjoy the entirety of the competitive market, might nevertheless by satisfactory evidence be able to establish loss of sales due to false advertising. The Court evidently set up the requirement of proof of exclusivity as the only satisfactory evidence of its loss of sales, which would inevitably establish per se, that any diversion of sales must have been at plaintiff's expense. Having concluded that in any event plaintiff was unable to show actual damage, the Court side-stepped a

12 Id. at 133. 
holding as to whether substantive law would have held forth a remedy if it could have done so.

In California Apparel Creators v. Wieder of California, ${ }^{13}$ the Court of Appeals for the Second Circuit, this time with Judge Learned Hand voicing a dissent, reapplied the rationale of the Supreme Court's approach to the Ely-Norris case, enlarging upon it in language, though not in thought. The plaintiffs comprised a trade association and group of companies manufacturing garments in California. Defendants designated their apparel "California" products, although they were not made in, and did not come from that state. The court, in dismissing the complaint upon motion, wrote as follows: ${ }^{14}$

This decision and the implication from the two opinions, [i.e., the opinions of the Supreme Court and the court of appeals in the Ely-Norris case] construed together, have been widely accepted as prevailing law. They constitute significant emphasis upon the need of individualizing the injury asserted, and thus point to the weak element of the plaintiff' case here. To recover damages or to receive protective relief against the actions of these defendants, plaintiffs must therefore show not only a representation by defendants which is false and deceitful in the sense of luring customers to their doors wrongfully, but also that plaintiffs have lost their own rightful custom thereby. ${ }^{15}$

The significance of the decision is underscored by the vigorous and clear terms in which Judge Hand couched the opposing theory which the majority rejected. ${ }^{16}$

As I understand my brothers, they do not dissent from the doctrine, which we laid down in Ely-Norris Safe Co. v. Mosler Safe Co., and which the Supreme Court did not disturb upon the appeal, though they disagreed with our reading of the bill of complaint. That doctrine is that it is untrue to say that a person aggrieved can never have protection against a competitor's false attribution of geographical origin to his goods, or his false de-

13162 F.2d 893 (2d Cir. 1947).

14 Id. at 900 .

15 The court continued, id. at 901:

"It is nowhere claimed that there is, or will be, available any proof of specific customers diverted from specific plaintiffs through the actions of these defendants. The only possible suggestion of injury is by a strained process of inference, as by the suggested conclusion that the general effect of defendants' actions must have diverted customers from the plaintiffs. Here we are inet with the direct difficulty found insurmountable by Justice Holmes in the Ely-Norris Safe Co. case, that there is no reason to assume that defendants' customers, deceived as to the place of origin, would otherwise have bought of these plaintiffs. Not only are these plaintiffs a small portion of the total California manufacturers, but they do not even appear to be large manufacturers themselves or to control any considerable portion of the California business. The reasons which led the Supreme Court to dismiss the bill in that case on its allegations are therefore inore pertinent here, where the limited extent of the plaintiffs' share of the total business definitely appears and is not merely a matter of inference, as there."

16 Id. at 902 . 
scription of their quality or character. We held that such false advertising will always be an actionable wrong, if the plaintiff can show that it has in fact diverted customers from him. The plaintiff' difficulty in the case at bar, if it ever came to trial, would be to show that the defendants' attribution to their goods of a false geographical origin did divert customers from them. That would be indeed difficult to prove, so difficult that, if it were necessary in addition to prove how much any one of them had lost in dollars and cents, I think I should go along with the decision we are making. However, it would not be necessary for them to make that proof in order to get an injunction; personally I should be satisfied, if any one of them proved that the defendants' advertisements had diverted, or would divert, his customers. If he did so, I should enjoin the defendants from continuing to get customers that way, just as I should enjoin them from getting customers by any other fraud. ... By hypothesis the defendants are injuring some one or more of the group; and he or they would get an injunction, if they could be ascertained; the others are not so entitled only because they have not been able to prove that they do not as yet need one. Faced with a choice between denying any remedy to those to whom a remedy is due, and extending it to those who do not need it, I should not hesitate.

California Apparel Creators was the last case of this line to be decided before section 43 (a) of the Lanham $\mathrm{Act}^{17}$ became effective. As such, it might well mark the close of the first period of evolution in this field, a period which saw the development of a begrudging concession by the courts that perhaps a hard and fast rule does not prevail that a plaintiff has no substantive riglut to relief against false competitive advertising even where he can prove direct and "individualized" damage therefrom.

What seemed to be needed was a firm statement that such a cause of action does exist, and that, as with most equitable relief by way of injunction, it can be asserted upon a showing of likelihood of damage without awaiting the actuality.

Section 43 (a) of the Lanham Act was enacted to achieve both these objectives. It reads:

Any person who shall affix, apply, or annex, or use in connection with any goods or services, or any container or containers for goods, a false designation of origin, or any false description or representation, including words or other symbols tending falsely to describe or represent the same, and shall cause such goods or services to enter into commerce, and any person who shall with knowledge of the falsity of such designation of origin or description or representation cause or procure the same to be transported or used in commerce or deliver the same to any carrier to be transported or used, shall be liable to a civil action by any person doing business in the locality falsely indicated as that of origin or in the region in which said locality is situated, or by any person who beheves that he is or is likely to be damaged by the use of any such false description or representation. [Emphasis added.]

1760 STAT. 441 (1946), 15 U.S.C. \$ 1125(a) (1952). 
The second stage of cases dealing with this subject orients around the question of whether section 43 (a) effectively changes the theretofore existing law, or whether it is merely declaratory of it.

This subject first received attention in the California Apparel Creators case, but since that case had been pending prior to the effective date of the Lanhain Act, it was unaffected by it. The court did not, therefore, go into the matter with any degree of thoroughness, but its general attitude appears to have been one of less rather than more enthusiastic acceptance of the new statute as the harbinger of any significant change in the law.

This rather chill overture to the judicial reception of section 43 (a) came rapidly to a crescendo in Chamberlain v. Columbia Pictures Corp. ${ }^{18}$ in which the Court of Appeals for the Ninth Circuit bluntly held that, Lanham Act or no Lanham Act, there is no federal cause of action for false advertising in the absence of passing off. The defendant had misrepresented one of its motion pictures as being a Mark Twain story. Plaintiffs, owners of copyrights in Mark Twain works, contended that by attributing authorship of a "corny" story to Mark Twain, the defendant lowered the public esteem for true Mark Twain writings, thus damaging the value of their copyrights.

The court said: ${ }^{19}$

At first blush it might be said that the allegations made fit snugly into the provisions of [Lanham Act section 43(a)] .... However, we do not think said section changes the fundamental requirements necessary to sustain a suit for unfair competition, one such requirement being a direct injury to the property rights of a complainant by passing off the particular goods or services misrepresented as those of complainant. Deceiving the public by fraudulent means, while an important factor in such a suit, does not give the right of action unless it results in the sale of the goods as those of the complainant.

The balance was brought back to center in 1954 when the Court of Appeals for the Third Circuit took square issue with the Ninth Circuit on this proposition in L'Aiglon Apparel v. Lana Lobell, Inc. ${ }^{20}$ In that case the defendant had published national magazine advertisements to promote the mail order sale of its dresses at a price of $\$ 6.95$. However, as a prominent feature of its advertisements it showed an actual plotographic reproduction of a dress being sold by the plaintiff for $\$ 17.95$.

While, as is apparent froin these facts, the case borders upon passing off, the court apparently disregarded that factor as a prop, since the defendant apparently had no such dresses to sell. Instead, the court pointed to the

18186 F.2d 923 (9th Cir. 1951).

19 Id. at 925 .

20214 F.2d 649 (3d Cir. 1954). 
plaintiff's allegations of trade diversion, and of the mistaken impression conveyed to those familiar with the advertising of both parties that plaintiff was offering for $\$ 17.95$ a dress worth only $\$ 6.95$. The court then proceeded, in the following language of unmistakable clarity, to associate itself with the view that section 43 (a) had indeed changed the theretofore existing law with respect to false advertising as a private tort: ${ }^{21}$

In relation to the language of Section 43(a) this complaint states about as plaim a use of a false representation in the description of goods sold in commerce as could be imagined. And plaintiff's alleged damage as a result of defendant's misrepresentation may well be demonstrable within the normal requirements of legal proof and in such way as to entitle plaintiff to relief authorized by the statute. Thus, Section 43(a) seems to cover this case clearly and without ambiguity.

What then is the difficulty? It is, if we rightly understand defendant's position, that before the 1946 enactment of this statute, federal courts had imposed such restrictions on liability for unfair competition that one in plaintiff's position could not recover for the kind of conduct here charged. Therefore, it is argued, federal courts should so construe the statute as to preserve these judge-made limitations on liability.

... [T] he view has been expressed judicially that ... [a limitation such as that of the American Washboard case should] be read into Section 43 (a) of the Lanham Act. Chamberlain v. Columbia Pictures Corp., 9 Circ., 1951, 186 F. 2d $923 . .$.

However, we reject this entire approach to the statute. We find nothing in the legislative history of the Lanham Act to justify the view that this section is merely declarative of existing law. Indeed, because we find no ambiguity in the relevant language in the statute we would doubt the propriety of resort to legislative history even if that history suggested that Congress intended less than it said. It seems to us that Congress has defined a statutory civil wrong of false representation of goods in commerce and has given a broad class of suitors injured or likely to be injured by such wrong the right to relief in the federal courts. This statutory tort is defined in language which differentiates it in some particulars from similar wrongs which have developed and have become defined in the judge made law of unfair competition. ... But however similar to or different from pre-existing law, here is a provision of a federal statute which, with clarity and precision adequate for judicial administration, creates and defines rights and duties and provides for their vindication in the federal courts....

In 1956 the Court of Appeals for the District of Columbia, by dictum, joined ranks with the Third Circuit. In S. C. Johnson \& Son, Inc. v. Gold Seal Company, ${ }^{22}$ the court of appeals affirmed "for the reasons given in District Judge Youngdahl's opinion," a judgment denying a counterclaim

21 Id. at $650-51$.

22230 F.2d 832 (D.C. Cir. 1956). 
by the defendant S. C. Johnson \& Son, Inc. against the plaintiff on the ground of alleged false advertising arising out of the fact that defendant designated its product "GLASS WAX" when, in fact, the product contained no wax at all.

The basis of the district court's denial of such relief was, however, that it did not find the designation deceptive in the material sense that it made any difference to purchasers of the product. It found no evidence that anyone who bought "GLASS WAX" did so because of a belief that it contained wax, or that anyone would have refused to buy it had he known the true facts. Thus, the court did not hold that section 43 (a) would not have conferred a right of recovery had the designation been proven to be actually a materially deceptive one. To the contrary, the court stated in a footnote: ${ }^{23}$

Cases cited by defendants to support their charge of deception involved marks which were deceptive or misleading in that they represented to the public that the article was something essentially different from the thing which they actually received. Here the evidence shows that customers sought a cleaner and were well satisfied. Had the evidence shown that customers bought the product as a wax for glass, a different problem would have been presented to the Court.

Even more pertinent, the court expressly reviewed the conflict in interpretation of section 43(a) between the Chamberlain and L'Aiglon cases and asserted that it preferred to adopt the latter's view. ${ }^{24}$

Although some concern has been voiced that certain language in the Gold Seal case is a throw-back to the pre-Lanham Act requirements that a plaintiff must "individualize" damage from false advertising in order to have a cause of action, it seems clear that the court was writing in that vein only with regard to the plaintiff's ability to recover monetary damages.$^{25}$

At this writing, therefore, hope seems warranted that, at least by virtue of section 43(a) of the Lanham Act, a person who is injured by the false advertising of his competitor need not be turned away by the courts with the cliche that the law provides him with no personal remedy in the absence of injury to a "property right" by "passing off."

However, if such a plaintiff is to prevail, it seens equally apparent that he must be prepared to make a strong factual showing on the following points, leaving as little as possible to the realm of the "self-evident," or to assumption, rationalization or judicial notice:

23 Gold Seal Co. v. Weeks, 129 F. Supp. 928, 934 n.10 (D.C. 1955). (Emphasis added.)

24 Id. at 939.

25 "We also deny relief under Section 35 of the Lanham Act in the form of an accoutnting for profits and damages. Suffice it to say Jolnnson's attempt to analogize Section 43 (a) to a libel action, making proof of actual damages unnecessary, is totally without support in law or reason. Pecuniary recovery must be mdividualized, loss of sales must be shown." Id. at 940 . (Emphasis added.) 
1. that the defendant's advertisement is in fact false;

2. that it actually deceives or has the tendency to deceive a substantial segment of its audience;

3. that such deception is material, in the sense that it is likely to make a difference in the purchasing decision;

4. that the particular plaintiff has been or is likely to be mjured as the result of the foregoing, either by direct diversion of sales from himself to the falsely advertising competitor, or by lessening of the good will which his own product enjoys with the buying public.

The approach used to prove each of these elements will vary, of course, in each individual case. Attorneys will do well, however, to consult with the marketimg research experts of their clients, or with those of independent organizations, since many processes have been refined in those fields for exploring buying behavior, consumer reactions and the effect thereon of particular advertising claims or campaigns.

In addition there may be available in some instances statistical information from which persuasive correlations may be extracted between the defendant's use of the offending claim and relative sales reactions of the competing products. Probably in no instance will one single item of evidence clinch the matter, but the cumulative effect of a variety of hines of proof, all tending in the same direction, may ultimately tip the scale. After all, a plaintiff need establish the foregoing elements only by a fair preponderance of evidence; it is not necessary that they be shown beyond a reasonable doubt.

In some instances it may prove particularly effective to examine the defendant's own advertising experts and personnel, as well as those from its advertising agency. Since they are the ones who decided that the alleged misrepresentation is likely to produce enough sales to warrant recommending the expenditure of substantial sums of money to advertise it, the chances are that their files, or their memories, will contain some substantiation of the position which they take with their management.

It seems ultimately inevitable, once falsity of an advertising claim is established, that after considering all the circumstances of the case a court will draw its own conclusion as to the materiality and likelihood of injury in the same way it always has done on the question of likelihood of confusion in trademark infringement and unfair competition cases. Thus, the courts might readily reason that an advertiser can hardly be expected to expend large sums of money to publicize a representation unless he believes that it will lead to sales of his product. It would also be a rare situation in which the advertiser would expect all such increased sales to come from newly created users of that type of product. Ordinarily, it is anticipated that the major increase will be at the expense of competitors. If, 
therefore, plaintiff occupies a substantial portion of that competing market, it would seem to follow that he is likely to contribute in just about that same ratio to whatever sales the defendant is able to capture from competitors by use of the allegedly false claim.

In "passing off" cases a judicial willingness has been shown to accept the defendant's own judgment as to the effectiveness of his simulation. "Indeed, it is generally true that, as soon as we see that a second comer in a market has, for no reason that he can assign, plagiarized the 'make-up' of an earlier comer, we need no more; for he at any rate thinks that any differentia he adds will not, or at least may not, prevent the diversion and we are content to accept his forecast that he is 'likely' to succeed." 20

Except for the dead hand of the pre-Lanham Act cases, there would seem to be no reason, in a false advertising case, why the courts could not say that they "need no more" than the defendant's "forecast that he is 'likely' to succeed" through the use of his chosen misrepresentation. The rupture of this old line of cases by section 43(a) now presents the courts with such an opportunity.

Until they have firmly mamifested an inclination to adopt this more sympathetic approach, however, it will be the better part of valor for the plaintiff's attorney to marshal all that he can by way of demonstrative evidence upon the elements outlined above.

26 American Chicle Co. v. Topps Chewing Gum, Inc., 208 F.2d 560, 563 (2d Cir. 1953). 